\title{
WHITE MEN IN AFRICA: CELATI, THEROUX, KAPUSCINSKI
}

\author{
GERHARD VAN DER LINDE \\ (University of South Africa)
}

\begin{abstract}
Sommario
L'argomento principale dell'articolo è la posizione del turista bianco in viaggio attraverso l'Africa secondo un itinerario alternativo a quello consumistico. Si distingue dal turista con un itinerario prescelto, però la sua bianchezza è sempre un'etichetta ineluttabile che predispone $i$ suoi rapporti con la gente e i luoghi visitati. L'alterità del continente offre un esilio temporaneo dall'Occidente, un distacco volontario, eppure il turista bianco rimane un estraneo, un distaccato collezionista di storie e impressioni.
\end{abstract}

The article focuses mainly on Gianni Celati's Avventure in Africa $(A A)$, but some aspects of the discussion are broadened to include Paul Theroux's Dark star safari $(D S)$ and Ryszard Kapuscinski's The shadow of the sun (SS). These texts present impressions and descriptions of people and places visited, with the narrator acting as a guide and filter for the reader, as in any typical travel narratives. The narrators also feature prominently as protagonists of their narratives, and the reader is made aware of the writing process as part of the journey itself.

The ostensible purpose of Celati's visit to Africa is to investigate the possibility of a documentary on traditional healers, that is, to document an example of authentic African culture. The idea of a journey in search of authenticity is contradicted by a note made 
soon after his arrival: "non so neanche cosa sono venuto a fare in Africa" (AA:10). This suggests an initial sense of disorientation, but later on, he comes to view a lack of purpose as desirable in itself: "non voglio neanche sapere cosa siamo venuti a fare qui" ( $A A: 149)$. In between his initial confusion and his eventual rejection of structure and purpose, experiencing what Rorato (2007:264) calls a growing "senso d'incertezza", Celati completes most of his journey, having realised that "un turista è un fantasma", an outsider, "trasportato in un posto a non far niente, tranne spendere soldi" $(A A: 17)$. He accepts his envisaged idleness and consumption without trying to counterbalance it by deliberately seeking out sights or points of interest, for example by referring to a standardised menu of destinations (Enzensberger, 1996:129). Despite the expectations created by the title, Celati mostly records fairly trivial everyday incidents, as they present themselves in the course of his journey. Guagnini (1998:99) also points out that Celati's "adventures" mostly concern everyday events, and that the authenticity of his destinations is under threat from an invasion by consumer culture: "l'avventura è la quotidianità in un mondo che sta per venir eroso dai segni della civiltà di massa". The serendipitous exploration of everyday life in Africa and the white traveller's attempts to come to terms with it form a thread that runs through the narrative and lends some coherence to Celati's journey.

Theroux's intention is to set out on a journey of discovery and investigation. Having lived and worked in Africa during the 1960s, he wants to see what changes have taken place since then. He intends "to go from Cairo to Cape Town [...] and to see everything in between" (DS:8). He avoids typical tourist routes and destinations, amongst others because he wants to be "Out of touch", to "disappear", to be "unobtainable" (DS:8). He approaches the 
journey "in a spirit of discovery", but also wants "to drop out" $(D S: 4)$. Africa is a suitable destination for this purpose, since it "is one of the last great places on earth a person can vanish into" $(D S: 4)$. Like most tourists, Theroux is on a "quest for experiences that are in contrast to [...] daily experience" (Wang, 2006:65). Yet, unlike the typical escapist tourist, Theroux does not seek a destination that would be "accessible and inaccessible, distant from civilization and yet comfortable" (Enzensberger, 1996:127). Since he views himself as a traveller, rather than a tourist, he aims to head into "the unknown" $(D S: 18)$. In order to avoid "the commoditization of the tourist experience" (Wang, 2006:69), he does not have a pre-arranged itinerary. Instead of the modern style of travel, in which one is transported swiftly to a few targeted destinations, he "needed to be able to link one place to another", to see and experience the "relationship between Here and There" $(D S: 51)$. For him, traveling in Africa "was like being on a dark star", since it is "the anti-Europe, the anti-West" (DS:125). The Africa of the typical white tourist is dismissed as "predictable, programmed", while the Africa of "sentimental memorists" is a world apart, of no interest for his journey. He wishes to avoid the modus operandi of most White travellers in Africa, who prefer safe routes through dangerous areas and maintain "a great distance from the general population" (DS:243). Although he mixes and interacts with the natives, for the most part he remains a "detached observer" (DS:315). In a sense, Theroux sets out to do "lifeseeing: observing the way the people one visits really live..." (Enzensberger, 1996:132). He is not interested in a safe and sanitised version of Africa, and he also does not want to be offered a kind of "designer" authenticity. 
Celati and his companion are set apart from the outset, both as whites and as tourists. The tourist is always, everywhere an intruder. He comes from the outside, and attaches himself like a foreign organism to the indigenous population. $\mathrm{He}$ is a dissonant presence in their everyday life, marked by his strangeness. He is always on the move, always in transit, on his way to the next destination. He belongs nowhere and cannot be assimilated, yet wants to be at home everywhere, if only momentarily. As an Italian, the locals associate Celati with famous brand names which carry the connotation of wealth and lavish consumerism; as white persons, he and his companion represent "non quello che siamo o crediamo d'essere, ma quello che dovremmo essere in quanto bianchi (ricchi, potenti, moderni, compratori di tutto)" ( $A A: 11)$. For the local population, whiteness as a physical marker of identity is important because of what it represents for them. Every white tourist inescapably receives the label of being part of the società di consumo, and he is automatically grouped with a preconceived collective which is vaguely defined in terms of broad stereotypes. The capacity to travel abroad in itself is taken as a sign of his privileged position, since "In a world divided between rich and poor, tourism is a powerful symbol of wealth and privilege [...]" (Jaakson, 2004:170). It is taken for granted that he is a wealthy person, because "international travel from developed to developing countries are inescapably contexted" in a world where there is a huge gap between the haves and the have-nots (Jaakson, 2004:171).

Bracketed and differentiated in this manner, white tourists are persistently targeted by locals who offer all kinds of services and products, or simply beg. Celati compares them to parasites "che si attaccano al corpo di qualche grande animale pieno di sangue", while white tourists are compared to "vacche da mungere" (AA:21). 
On the one hand, the parasites, numerous and unproductive, dependent for their survival on a host, to which they instinctively and ruthlessly attach themselves; on the other hand, the slow and cumbersome host, who cannot avoid being preyed upon. The first comparison may seem derogatory, but it is used without condescension. It suggests an inversion of the colonial situation, in which foreign colonisers preyed upon colonised territories, with the presumedly wealthy descendants of the colonists now being preyed upon by the impoverished descendants of previously exploited countries. The self-mockery implicit to the second comparison is continued in Celati's reference to himself as "sempre troppo catturabile", especially because "guardo troppo in giro" ( $A A: 14)$. For the local population, his excessive curiosity and a tendency to make eye contact indicate him as an easy prey, "come pingone da mungere" (AA:14). The local population's perceptions of the white tourist are determined by codes which he has to learn the hard way.

Theroux also finds that it is part and parcel of being a white traveller in Africa to be targeted everywhere by locals who want to take money off you in exchange for all kinds of products and services, from sex to doing the job that they are in any case paid to do. This sometimes degenerates into cynical exploitation, when "every smile has a price" (DS:48). In some places, the white traveller is targeted by beggars, who ask or demand drink, food or money $(D S: 153)$. In others, he can fall prey to "the usual crowd of urchins, idlers, the homeless, the scavengers, the opportunists", who may rob him and afterwards mock his "stupidity" (DS, 189). In general, the White tourist is regarded as a vehicle for generating income, and as such, he is fair game.

Kapuscinski, writing on visits to Africa over a period of forty years, recounts that he found himself being exploited in a similar 
manner, and even being robbed repeatedly (SS:108), especially since he deliberately chose not to stay in a safe neighbourhood. Traveling by car, if one stops "even for a moment", one is immediately surrounded by women and children "selling everything and anything a traveller might need" ( $S S: 156)$. Moreover, "there are thieves everywhere" (SS:157). On one occasion, his travel documents are stolen by people who then offer their assistance and protection, at a fee (SS:233-235). He meets a Frenchman who "had been robbed of everything the second he stepped off the train" (SS:279). The reason for targeting white travellers in these ways is "the belief of many Africans that the white man has everything, or that, in any event, he has a great deal, much more than the black man" (SS:276). This statement echoes Celati's observation that he was regarded as wealthy and privileged simply by virtue of being white.

Thus, even in a postcolonial context, the white traveller is associated with wealth and privilege, which is hardly surprising in view of the poverty and unemployment that Celati and the other writers discussed encounter on their travels. However, this status no longer translates into a position of power, since the white man's situation as a postcolonial traveller is precarious and transitory. The rules of the game are not only beyond his control, they are often unknown to him or even improvised by people who are well versed in the art of surviving in difficult circumstances. The white traveller's privileged position makes him vulnerable, and his whiteness leaves him nowhere to hide. The experiences narrated by Celati and the others can be read as an ironical variation of what Wang (2006:70) calls the "alternative constraints" experienced by tourists who eschew the commercialism of pre-arranged itineraries, 
"such as the network of schedules, traffic lines and prices, and booking systems of transportation and hospitality".

In Celati's narrative, white men are not only set apart by their perceived affluence, they are also separated physically, in that they are assigned designated spaces, isolated from the local population, spaces that seem impenetrable, as if white tourists inhabit a parallel world: "[...] siamo incastrati in questo bunker, contornati dal muro del giardino che si tiene al riparo, separati dalla città con mezzo chilometro di vuoto" ( $A A: 64)$. In some places, this designated space is a residue of the colonial era, such as an "Albergo coloniale" $(A A: 149)$. Even if this space no longer carries the connotation of entrenched privileges and positions of power, it is still linked to enforced separation from the local population, a kind of reverse apartheid: "Come in tutte le situazioni coloniali, si vive nel ghetto dei bianchi" (AA:149). The accommodation spaces where Celati ends up are a haphazardly constructed variation on the "environmental bubble of conventional tourist services" (Urry, 1990:8).

Outside these spaces, white tourists follow certain conventions which define them as a collective, without creating a sense of solidarity or community: "hanno una divisa comune", but "evitano di guardarsi l'un con l'altro" (AA:21-22), following the rule to "far finta di non vedersi quando si incrociano per strada" ( $A A: 11)$. Each moves in a private space, "due metri cubi di vuoto spinto", as if barricaded behind "i muri della sua privacy che si è portato dietro da casa" (AA:22). In itself, the insistence on a personal space, defining "a boundary around the self", that "is carried everywhere one goes" (Altman, 1975:53-54) is not unusual, but Celati highlights the rigidity with which it is maintained by white tourists in Africa, not out of necessity, but as a means of setting themselves 
apart as a group and as individuals in that group. Celati suggests that insularity and individualism are part of the white tourist's identity, as well as a kind of conformism which dictates identification with a collective, without overcoming detachment and lack of cohesion between individuals.

In addition to the detachment between them, Celati's white tourists experience a sense of alienation with regard to the people and places they visit in Africa. They relate to the African milieu as onlookers visiting exhibits on display: "spettatori civilizzati dietro un vetro" (AA:15). The differences separating them from the local population are a given of their situation, since the objects of the "tourist gaze" are by definition distinct "from what is conventionally encountered in everyday life" (Urry, 1990:11). This is reinforced by the perception, created by TV news "che in Europa si vive tranquilli e pacifici" $(A A: 15)$, in contrast with endemic violence in Africa. For the "post-tourist" (Urry, 1990:11), the otherness of the tourist destination becomes a construct, made up of real and perceived or illusory differences.

The local population sometimes even behave as if they are on display, such as the half-naked women washing themselves in the Niger, unconcerned by being watched. $(A A: 33)$. The tourist gaze seeks out sights such as these, everyday "activities within an unusual visual environment" (Urry, 1990:12), or unfamiliar sights and sounds, such as the symbols of African mythologies and of African religious customs, which the secularised white tourist, having lost "a sense of the sacred" (Klopp, 2001:344) can only watch with amazement and uncomprehension from behind "il nostro schermo di vetro" (AA:35). Celati indicates that the tourist gaze is reciprocated, inasmuch as the white tourists in their turn become notable "sights" because of their strangeness. For example, 
the local adult population is generally reticent about public nudity, so that the tourists' habit of wearing shorts mark them as "bambinoni" $(A A: 33)$.

Ignorant of the local population's cultural and religious codes, the white tourist is also uncomfortable with the texture of African urban spaces. The segmentation of space to which he is used, the separation between everyday life and its byproducts is replaced by integration. The white onlooker is astonished to find that Africans routinely share their public spaces with all kinds of waste. When Celati looks for a space "dove gettare le bucce", he is told that "potevo gettare le bucce per terra" (AA:39). All around him, "per terra era un tappeto di spazzatura, cartacce, fango, bucce, putredine e sestolame" (AA:39). For the local population, the urge to create a distance between the body and the waste it generates, by removing it out of sight to designated spaces is yet another sign of the white man's strangeness, and turns him into an object of ridicule. They seem to be at home in this kind of disorder, adapting the rhythm and direction of their movements to the "quantità di roba sparsa per la piazza" (AA:46).

Theroux is equally struck by the dirt and mess he encounters in Egypt, ranging from mere "garbage and litter" to the contents of chamberpots, "thrown from upper balconies", to "pissed-on walls" $(D S: 9)$. On a train journey, he notes the mess created by other passengers, and the lack of effort at cleaning up, remarking that "the dirt, the litter, the shit and the drunks" made this journey "hard to bear" (DS:266). A similar experience awaits him in Dar es Salaam, where he encounters people "emptying chamber pots, a man pissing against a post", which prompts the remark "whenever I arrived in an African city I wanted to leave" (DS:267). In Kampala, he notes a pattern common to many African cities, namely, "Nothing is fixed 
or kept in good repair, the concept of stewardship or maintenance hardly existed" (DS:213). Such phenomena confirm Theroux's perception of Africa as the "anti-West". In some cases, disorder is a sign of a break with the colonial past and the re-integration of precolonial practices into the present. Theroux finds the erstwhile club in Malawi to be run down and abused, as colonials predicted would happen if "Africans" were allowed entry (DS:320). He describes the prediction as "offensive" but "fairly prescient" (DS:320). While the colonisers' exclusion of Africans was based on a sense of racial superiority, the club's state of disrepair signals the superfluity of the customs and practices associated with it. It simply has no place in postcolonial Africa.

Kapuscinski, traveling through Liberia, notes, "Here, if anything is destroyed, broken, ruined, it will simply be left that way [...] If a tree trunk falls across the road, it will not be removed [...] An unfinished house will stay unfinished, a ruined one will stay ruined" (SS:259). Elsewhere, a large pothole is left unrepaired because it can be used to generate business and provide employment (SS:304).

Thus, viewed through Western eyes, in many instances African spaces seem to be in a state of uncontrolled entropy. For the white tourist, this is a strange world in which he feels out of place, but which creates a sense of authenticity, in that it offers sights that are far removed from the marketing brochure and the consumerfriendly itinerary. However, even this alternative tourist experience follows a pattern of repetitions and similarities, as if Celati and the other writers are actors in the same underlying script, albeit one of which only the broad outlines are predetermined, if not by design, then by circumstances. The authenticity of the alternative experience does not lie in the fact that it corresponds to a preconceived notion of what constitutes the "real Africa" - and 
none of the writers discussed offers such a notion - but in its capacity to take the white tourist as far as possible from the patterns of his familiar lifestyle, while avoiding the predefined shape and intentionality of a structured product. In this sense, dirt, garbage and disrepair also become unfamiliar sights sought out by the tourist gaze. Some of the scenes described by Theroux and Celati suggest multisensory experiences, unpleasant but authentic in that the tourist is publicly confronted with sights and smells which offer a stark contrast both to the sanitised environment to which he is used and which he accepts as the norm and to the romanticised Africa of spectacular landscapes and exotic wildlife.

Celati's initial reaction to the absence of waste and garbage management reflects the white tourist's need to have "qualcosa sotto controllo" in order to avoid a sense of disorientation. In a context shaped by modernisation, reason imposes itself on the body's lifeworld, leading to the rationalization of public spaces. The white man's body is conditioned to move in orderly spaces, always looking for "percorsi rettilinei", seeking to be in control of his surroundings, which he views "con sguardi di sorveglianza a novanta gradi" (AA:135). Urry (2007:66-70) describes how the restructuring of European cities such as Paris and Vienna in the nineteenth century facilitated the movement of pedestrians, thereby creating opportunities for exploring the city on foot, and presenting neatly ordered visual landscapes. In such an environment, the tourist moves around easily and comfortably, and sights are easily identified. Large open spaces create areas for relaxation and encourage leisurely navigation, while also serving as directional pointers.

By contrast, "'disorganized tourist spaces"' necessitate, amongst others, "less rigid bodily postures and a more casual wandering and 
lounging" (Urry, 2007:72). This is especially true of urban spaces similar to those encountered by Celati's tourists, where confusion seems to reign, and surfaces are "uneven, [and] full of rubble" (Urry, 2007:72). They struggle to make the tactical adjustments required to navigate these spaces. Even in the orderly environment of a hotel, their movements are rigid, lacking the fluid rhythms of the African bodies around them, because they always need to control, if not their surroundings, then at least themselves. This is conveyed "con gli sguardi, con i vestiti, con le automobili, con i calzoni corti di vacanza, con tutti i segni della moda oppure col fucile da cacciatore" $(A A: 136)$, that is, by demonstrating that they have the appropriate tools for dealing with specific situations in which they find themselves. The need to control prevents them from living fully in the "indistinto presente"; instead, they always focus on the vicarious reality of "una mappa", of "un codice legale", they are oriented towards a possible future which they create by planning it, or towards the known past (AA:136). They are out of place in the African spaces which in Celati's presentation seem devoid of a historical dimension and lacking in a future perspective, wholly taken up by the disorderly flow of everyday existence.

Celati remarks that white tourists form a coherent group, with their own beliefs, mythology and conventions, "un vero popolo" (AA:163). To some extent, this is true of tourists in general. Graburn (2004:27-29) describes tourism as a kind of ritual, involving conventionalised preparations, and often resulting in the establishment of tourist communities, where individual differences are smoothed over through the introduction of localised customs and conventions. For Celati, an Italian living in Paris and a stranger in Africa, white tourists constitute a transnational collective which in a globalised world is perhaps the only "nation" to which he can 
still belong. Yet, in contrast with the usual white tourist in Africa, he grows to enjoy "la fluttuante confusione di tutto", a situation in which "proprio niente sembra sotto controllo" (AA:174). He also becomes more tolerant of the discrepancy of elegant women "accucciate accanto a mucchi di spazzatura", less disconcerted by "questa indifferenza al putride, da noi inammissibile" ( $A A: 174)$. Celati does not indicate whether this tolerance is based on a kind of cultural relativism, or whether he simply becomes used to the mess and confusion. It is at least partly motivated by a critical attitude towards the Western way of life, which emerges through contact with the everyday realities of Africa.

Reflecting on the possibility that Africa will become Westernised, Celati contrasts the typical Westerner's tendency to be "maniaci del tutto sotto controllo" with Africans' apparent tolerance of "il disordine naturale delle cose" (AA:175). When he notices numerous informal traders at the airport lying in wait to target unsuspecting tourists he describes the scene as "uno spettacolo da non perdere", and suggests that it is "più interessante delle nostre commedie da cartellone" ( $A A: 176)$ : on the one hand, a real life drama that will develop unpredictably and without fixed rules, on the other, a stylised spectacle governed by known conventions, and designed for easy consumption. Celati refers ironically to Western tourists'fascination with African artifacts, which implies the commoditisation of otherness, and which they accept as authentic inasmuch as it conforms to their preconceived notions of what constitutes its authenticity: "Cornice finale, veramente africana, per americani" (AA:177). By implication, he distances himself from what he views as Westerners' tendency to artificiality and their preoccupation with control, highlighted by his encounter with what he perceives to be Africans' relative naturalness and flexibility. 
If his encounter with Africa is like a series of sights and events on display, which he views as a detached and uninvolved onlooker, Celati realises that life in Paris is just as much a spectacle, also witnessed from behind a "schermo di vetro" $(A A: 179)$. In that sense, even at "home" he remains a tourist. The difference is that the Western city offers a spectacle of material excess and abundance. The onlooker to this spectacle may find that he lacks nothing, except the "niente che non si può comprare", the "niente che hanno gli altri che non hanno niente" (AA:179). One of the symbols of this excess is the singer Madonna, who became an icon of pop culture by inventing and reinventing herself as a series of products under the brand name "Madonna", a pliable consumer object with no fixed identity (Bego, 1992:3-8; Fouz-Hernández \& Jarman-Ivens, 2004:xvi). Images of the star are on display in Africa as well, but they are stripped of their glamour, and even discarded: "Ho anche visto l'insopportabile Madonna nell'immondizia, la sua faccia già sbiadita tra gli avanzi" $(A A: 174)$. In the West, she is part of a culture of excess which is always in search of new products, insatiably consuming throwaway objects. As witnessed by Celati, in Africa, decoupled from the circuit of marketing and consumption, the Madonna poster merely becomes a thrown away object, "senza più la redenzione di un'aureola pubblicitaria" $(A A: 174)$. For those who have nothing, there is no promise of constant regeneration, of continuously redesigned products. It is this "nothing" which cannot be bought, this lack of means which would have offered an escape route from the never-ending cycle of production, consumption and redesign, if it was possible for Western consumer culture to buy its own redemption. Despite these considerations, Celati does not idealise Africa as the potential haven for an alternative lifestyle, and his narrative shows how Africans' lack of means leads them to 
target the white tourist as source of income and representative of consumer culture.

For Theroux, Africa provides the ultimate experience of otherness. In this respect, he compares himself to Rimbaud, who went into voluntary exile in Africa, which he viewed as "the antiEurope, the anti-West" (DS:124). In Theroux's view, "there was nothing of home here. Being in Africa was like being on a dark star" $(D S, 124)$. Part of the source of his happiness as a traveller derives from the opportunity to live in a different rhythm sometimes erratic and unpredictable, always unhurried. It is a kind of existence reduced to what for him are the basic necessities (DS:240), far removed from the material comforts and abundance of his Western lifestyle, but it is also just a parenthesis, a temporary escape. He finally returns from Africa, "robbed and diseased" $(D S: 405)$. The parasites he picked up on his return journey become a metaphor for "Africa stirring inside me", underlining his ambiguous relationship with its otherness, which attracts and fascinates, but remains incompatible with the white tourist, a toxic and foreign presence in his body ( $D S: 405)$.

While Celati's narrative offers an almost ahistorical perspective, and moves in the here and now (Klopp, 2001:340), Theroux's displays more awareness of the postcolonial context in which the traces of his personal involvement with the continent have been irrecoverably erased. His experiences as a tourist are similar to Celati's, but because of the historical perspective, there is a strong sense of disillusionment in Theroux's account: Africa does not seem to have improved since his previous visit. For Theroux, the "niente" which Celati presents as a counterpart to the West's consumer culture is part of a struggle for survival brought about by corruption and mismanagement and unrelieved by ineffective development aid. 
He views poverty and suffering in concrete terms, not as an abstract "niente", and therefore, for him, they do not represent any positive values and can never be desirable in any way. At the same time, he views Western aid workers as intruders whose solutions are imposed from the outside while they themselves are set apart, never assimilated into the local population.

Celati's narrative is presented as a diary, written day by day as part of his journey, while Theroux's is presented as based on notes compiled during his travels. On the one hand, the reader meets with alienation from, and occasional enjoyment of the flow of everyday confusion and disorder, recorded in the moment, which gives the narrative a fragmented and impressionistic flavour, postmodern in the sense that it is not guided by or integrated into any overall framework, and therefore inconclusive and with no claims to offering any generalised "truths" or explanations. Celati simply records his observations and reflections, without claiming to understand (Klopp, 2001:339), on the contrary, he suggests that the realities of Africa cannot be grasped from within his Western framework of reference. On the other hand, one finds a journey of discovery and rediscovery, told in retrospect, recounting an adventuresome itinerary, stories collected along the way, and recollections of a youthful involvement with the continent. Each in its own way, both narratives present the white tourist's attempts to come to terms with aspects of Africa's otherness which have not been sanitised and repackaged for easy consumption, and his awareness of the boundaries set by his own strangeness, as a foreign presence on the continent. 


\section{REFERENCES}

\begin{tabular}{|c|c|c|}
\hline Altman, I. & 1975 & $\begin{array}{l}\text { The environment and social behavior. Monterey: } \\
\text { Brooks/Cole. }\end{array}$ \\
\hline Bego, M. & 1992 & $\begin{array}{l}\text { Madonna: blonde ambition. New York: Harmony } \\
\text { Books. }\end{array}$ \\
\hline Celati, G. & 1998 & Avventure in Africa. Milano: Feltrinelli. \\
\hline Enzensberger, H.M. & 1996 & $\begin{array}{l}\text { A theory of tourism. New German critique, } \\
68: 117-135 \text {. }\end{array}$ \\
\hline $\begin{array}{l}\text { Fouz-Hernández, S. } \\
\text { \& Jarman-Ivens, F. }\end{array}$ & 2004 & $\begin{array}{l}\text { Introduction. In: Idem (eds.) Madonna's drowned } \\
\text { worlds: new approaches to her } \\
\text { cultural transformations. Farnham: Ashgate: i- } \\
\text { xxii. }\end{array}$ \\
\hline Graburn, N.H. & 2004 & $\begin{array}{l}\text { Secular ritual: a general theory of tourism. In: } \\
\text { Bohn Gmelch, S. (ed.) Tourists and tourism. } \\
\text { Long Grove: Waveland Press:23-34. }\end{array}$ \\
\hline Guagnini, E. & 1998 & $\begin{array}{l}\text { Italiani in Africa da Scarfoglio a Celati. } \\
\text { Narrativa, 14:89-101. }\end{array}$ \\
\hline Jaakson, R. & 2004 & $\begin{array}{l}\text { Globalisation and neocolonialist tourism. In: Hall, } \\
\text { C.M. \& Tucker, H. (eds.) Tourism and } \\
\text { postcolonialism. London:Routledge:169-183. }\end{array}$ \\
\hline Kapuscinski, R. & 2001 & Shadow of the sun. London: Allen Lane. \\
\hline Klopp, C. & 2001 & $\begin{array}{l}\text { Buster Keaton goes to Africa: Gianni Celati's } \\
\text { Avventure in Africa. In: Matteo, S. (ed.) } \\
\text { ItaliAfrica: bridging continents and cultures. } \\
\text { Stony Brook: Forum Italicum:337-347. }\end{array}$ \\
\hline
\end{tabular}


Rorato, L.

Theroux, P.

Urry, J.

Urry, J.

Wang, N.
2007 Casi esemplari di turismo africano: la figura del turista in Avventure in Africa di Gianni Celati. Italica, 84(2-3):262-273.

2003 Dark star safari. London: Penguin Books.

1990 The tourist gaze: leisure and travel in contemporary societies. London: Sage.

2007 Mobilities. Cambridge: Polity Press.

2006 Itineraries and the tourist experience. In: Minca, C. \& Oakes, T. (eds.) Travels in paradox: remapping tourism. Lanham: Rowman \& Littlefield:65-76. 